\title{
Frosne konflikter - eller varme kartofler?
}

Af Karsten Jakob Møller

Frosne konflikter er konflikter, der trækker i langdrag. Konflikten lever stadig og venter på enten at bryde ud igen eller at blive løst. Det er ikke en stationær tilstand, for under overfladen arbejder de involverede parter målrettet på at ændre status quo til egen fordel.

Vil kamphandlingerne i det østlige Ukraine føre til en ny 'frossen konflikt'? Det er der mange, der mener, inklusive undertegnede, selvom konflikten stadig er ganske 'varm' og kan udvikle sig i flere retninger - herom senere. Men hvad er egentlig en 'frossen konflikt'?

Der kan nævnes mange eksempler på frosne konflikter, fx Jammu-Kashmir, Cypern, Kosovo og Bosnien-Hercegovina. Men umiddelbart vil de fleste nok tænke på uløste konflikter i det post-sovjetiske rum: Nagorno-Karabakh, Abkhasien, Sydossetien og Transnistrien, men der er mange flere andre steder på kloden. Denne artikel vil undersøge problematikkerne omkring begrebet 'frosne konflikter' og finde karakteristika, ligheder og forskelligheder i de eurasiske konflikter med vægt på Sydkaukasus, Transnistrien og i mindre grad på Balkan.

Afslutningen af den kolde krig medførte ikke 'den evige fred', som mange havde håbet på; tværtimod fjernede den låget over en lang række etniske og nationale konflikter, der havde ulmet under overfladen. Etniske minoriteters frygt $\mathrm{i} ø \emptyset l v a n d e t$ på en ofte aggressiv nationalisme i de ny stater - tilsat traditionel magtpolitik - var nogle af årsagerne til disse konflikter.

En 'frossen konflikt' kan karakteriseres som en kompleks tilstand, hvor en voldelig etnisk-politisk konflikt om løsrivelse fra 'moderstaten' har ført til etableringen af et de facto styre, der hverken er anerkendt af det internationale samfund eller den stat, det har løsrevet sig fra. Krigshandlingerne i forbindelse med løsrivelsen vil i det store og hele være ophørt, men den politiske aktivitet fortsætter mere eller mindre intensivt.

Den engelske fagterminologi er som oftest 'protracted conflicts', dvs. konflikter, der trækker i langdrag, hvilket er mere præcist, for konflikten lever stadig og venter på enten at bryde ud igen eller at blive løst. Der er ikke tale om en stationær tilstand, for under overfladen arbejder de involverede parter målrettet på at ændre status quo til deres fordel. Netop tidsfaktoren er vigtig. Fraværet af konstruktive tiltag, mangel på tillid og forsoning bliver over tid forstærket af parternes propaganda. Parternes narrativer bundfælder sig hos de respektive parter og bidrager til forlængelse af konflikten.

Karsten Jakob Møller er seniorforsker ved Dansk Institut for Internationale Studier. 


\section{Fællestræk}

Typisk opstår denne type konflikter i stater, hvor der befinder sig en minoritet med en særskilt etnisk-national identitet, og ofte deler en af nabostaterne denne særskilte identitet. Det kan være resultatet af en annektering eller en grænsedragning, hvor minoriteten efterlades på den 'forkerte' side af grænsen, fx serberne i Kosovo.

Nogle minoriteter ønsker at blive (gen) forenet med den pågældende nabostat, som $\mathrm{fx}$ Sydossetien, der, selvom den p.t. er udråbt som selvstændig stat, ønsker at blive forenet med Nordossetien, der er et føderationssubjekt i Rusland. Sydossetien anerkendes dog kun af ganske få stater, først og fremmest Rusland. Andre ønsker fuldstændig uafhængighed, som $\mathrm{fx}$ abkhaserne, der som bekendt er udråbt som selvstændig stat, men ligesom Sydossetien kun anerkendes af en håndfuld stater.

Et fælles træk er her, at man ser sig selv som en ensartet etnisk gruppe i et afgrænset område og med et eget politisk system. Man anser sig i social og økonomiske henseende bedre tjent ved en adskillelse, i dette tilfælde fra Georgien. For serberne i Kosovo er situationen lidt anderledes, idet den serbiske befolkning godt nok ønsker sig forenet med Serbien, men er spredt over en stor del af Kosovo, hvorfor en genforening ville få betydelige - og uacceptable - følger for den Kosovoalbanske majoritet og dermed være uacceptabelt for det internationale samfund.

Endelig ønsker nogle en form for regional autonomi, men inden for den pågældende stats grænser, $\mathrm{fx}$ Adjarien, der nu er en selvstyrende republik i Georgien. Krav om betydelig autonomi kan føre til konflikt, men kan også være en del af en konfliktløsning, afhængig af de krav til autonomi, der stilles af den pågældende minoritet.
I sin mest vidtgående form kan der ikke blot blive tale om separate politiske strukturer, men også egen møntfod og juridisk system. Oftest vil der blive stillet krav om anerkendelse af sprog, religion og kultur og finansiering af separate skoler. I yderste konsekvens er der tale om de facto uafhængighed, men den pågældende stat opretholder i det mindste suveræniteten over det pågældende område. Bosnien-Hercegovina er vel et eksempel herpå, selvom intentionerne $\mathrm{i}$ Dayton-aftalen var anderledes.

Imidlertid er autonomi ikke nødvendigvis løsningen på en konflikt. Inden for minoriteterne kan der være - og er som oftest - grupperinger, der kun stiller sig tilfreds med fuld suverænitet eller genforening; de bosniske kroater og de bosniske serbere er eksempler herpå.

Autonomi kan tillige inspirere andre minoriteter i det pågældende område til øget selvstændighed og det kan skabe usikkerhed, der kan føre til direkte konflikt. Da Kroatien i 1991 erklærede sin selvstændighed i forhold til Jugoslavien, udløste det en reaktion fra en serbiske befolkning i Krajina, der nægtede at anerkende kroatisk herredømme og derfor etablerede sin egen autonome region, indtil denne blev nedkæmpet af kroaterne i 1995 i den af mange danske soldater bekendte Operation Storm.

\section{Etniske minoritetskonflikter}

Forskellige politiske metoder har været bragt i anvendelse for at løse etniske minoritetskonflikter.

Den mest radikale metode er folkemord, dvs. systematisk drab på eller indirekte tilintetgørelse af bestemte etniske grupperinger ved fx tvangsforflyttelser. Det værste eksempel i nyere tid er utvivlsomt de tyrkiske massakrer på og tvangsdeportation af mere end 1.000.000 
armeniere i 1915. Men den serbiske massakre under ledelse af Radovan Karadic og general Mladic på den muslimske befolkning i Srebrenica, en ugerning, der kostede ca. 8.000 muslimske bosniere livet, falder uden tvivl ind under begrebet folkemord.

En anden metode, der er beslægtet med folkemord, er etnisk udrensning, som kan lede til folkemord, men som oftest medfører fordrivelse af befolkningsgrupper til andre områder eller lande, med langvarige ophold under ofte kummerlige forhold i flygtningelejre til følge. Denne metode har været anvendt af serberne over for de bosniske muslimer og Kosovo-albanerne, mens kroaterne har anvendt den mod Krajina-serberne.

De to ovennævite metoder må betegnes som ineffektive, da de som oftest modvirker den egentlige hensigt. De skaber på længere sigt flere problemer, end de løser, og medfører som hovedregel kraftige reaktioner fra det internationale samfund.

En tredje mulighed er en opdeling af en stat $\mathrm{i}$ to eller flere anerkendte stater. Indien/Pakistan, Korea og Palæstina er eksempler herpå, men falder uden for denne artikels rammer, da der er tale om afvikling af kolonier, dog ikke for Korea, hvis deling er et produkt af den kolde krig. Løsrivelse er en hyppig anvendt mulighed, hvor en mere eller homogen gruppe forlader en stat ved at erklære sig uafhængig eller ved at tilslutte sig en etnisk beslægtet stat.

Jugoslaviens opløsning begyndte med Sloveniens løsrivelse, der i princippet var uproblematisk, fordi Slovenien er et befolkningsmæssigt homogent område. Kroatien derimod havde et betydeligt serbisk mindretal på sit territorium, hvilket initierede den borgerkrig i det tidligere Jugoslavien, der varede frem til 1996, hvis vi ser bort fra konflikten i Kosovo, der var under udvikling og først fandt en løsning senere.

De kroatiske bosniere og de bosniske serbere ønskede - og ønsker vel stadig løsrivelse og dermed tilslutning til henholdsvis Kroatien og Serbien, hvilket var den væsentligste årsag til de langvarige kampe i Bosnien-Hercegovina. Det internationale samfund ville dog i sidste ende ikke acceptere en muslimsk enklave i Bosnien, der var uden et reelt eksistensgrundlag.

I stedet blev der med Dayton-aftalen skabt en føderativ struktur, der i virkelighedens verden har vist sig at være dysfunktionel og bl.a. har medført, at situationen er blevet yderligere fastfrosset, og at Bosnien er blevet bistandsklient i det internationale samfund, først og fremmest EU.

Blandt de mere fredelige metoder til eliminering af minoritetsproblemer er assimilering og integration. Ved assimilering forsøger en stat at transformere minoriteterne til borgere i staten på lige fod med flertallet. Det indebærer ofte, at de må give afkald på deres sprog, religion og kultur og må acceptere et nationalistisk pensum i skolerne og sågar sprog- og loyalitetstests. Det er en mere eksklusiv tilgang, i modsætning til den inklusive, der forsøger at udnytte mangfoldigheden til at styrke samfundet. Her de tre baltiske landes tilgang til de russiske mindretal et illustrativt eksempel.

En konsekvens heraf kan være en 'sikkerhedsliggørelse' (for nu at bruge Ole Wævers begreb) af mindretallene, hvorved de betragtes som en sikkerhedstrussel for staten, hvilket igen medfører foranstaltninger til at inddæmme denne trussel. Assimilering fører ikke nødvendigvis til en varig løsning på konflikten. Mindretallets vilkår kan blive af en sådan karakter, at konflikten blusser op igen. 
Forskellige politiske metoder har været bragt i anvendelse for at løse etniske minoritetskonflikter. Den mest radikale metode er folkemord, dvs. systematisk drab på eller indirekte tilintetgørelse af bestemte etniske grupperinger ved fx tvangsforflyttelser.

Modsætningen hertil er integration, hvor man tilstræber at gennemføre en forsoningsproces, der respekterer mangfoldigheden inden for rammerne af statsborgerskabet. Man tillader minoriteten at udøve dens religion og kultur, så længe det er begrænset til den privatesfære.

Der er kort og godt tale om en afpolitisering af forskellighederne, af nogle forskere kaldt en 'privatiseringsstrategi'. I det foregående er beskrevet og analyseret den lokale dimension i konfliktområder. Men det der også karakteriserer disse konflikter, er det forhold, at det internationale samfund hurtigt forsøger at få bragt den væbnede konflikt til ophør, og at eksterne aktører ofte blander sig i konflikten. Det kan være internationale organisationer som FN, OSCE, EU, Europarådet og NATO, men også regionale stormagter, i det postsovjetiske rum først og fremmest Rusland.

De 'frosne konflikter' har således også en geopolitisk dimension, som er snævert forbundet med den lokale.

Eksterne aktører kan spille en positiv rolle i processen, der skal føre til en løsning af en given konflikt, men kan også af geopolitiske årsager bidrage til en fortsat fastfrysning. Ikke mindst er Rusland blevet kritiseret for at forfølge egne geopolitiske interesser i det post-sovjetiske rum og bidrage til at opretholde status quo i de sydkaukasiske konflikter og i Transnistrien.

\section{Nagorno-Karabakh}

Nagorno-Karabakh har som bekendt erklæret sig for selvstændig stat, men er i realiteten forenet med Armenien, som man er helt afhængig af, såvel økonomisk som militært. Nagorno-Karabakh anerkendes da heller ikke som selvstændig stat af det internationale samfund. I konflikten med Aserbajdsjan opretholdes status quo, men det er en forkert betegnelse at kalde den en frossen konflikt. Den er brandvarm. Der dør hvert år en 20-30 soldater ved frontlinjen. Parterne er grupperet over for hinanden i et stærkt udbygget skyttegravssystem, der er Første Verdenskrig værdigt, og et stykke tilbage står panserbataljonerne klar i højt beredskab, hvis der skulle ske et gennembrud af fronten.

Før krigen med Aserbajdsjan bestod flertallet i området af armeniere, og under krigen fandt der en etnisk udrensning sted af azerierne (ca. 800.000 fra Nagorno-Karabakh og de omgivende seks distrikter, som Armenien har besat) Til gengæld har området fået tilført ca. 230.000 armeniere, der flygtede fra de massakrer i Baku, der dannede optakt til konflikten.

Azerierne er et folk, der er beslægtet med Tyrkiet og derfor også støttes af Ankara og andre muslimske lande. Armenien har en enkelt forbundsfælle, Rusland, der også har militære styrker i landet. Parterne er uforsonlige over for hinanden, og på trods af flere russiske forsøg på mægling er faren for en genoptagelse af væbnet konflikt overhængende.

Konflikten har store geopolitiske implikationer for hele Sydkaukasus og dermed for Rusland og dets interesser i området. Rusland udnytter derfor sine muligheder for at kontrollere parterne; nogle kalder det 'kontrolleret ustabilitet'. 
Armenien er selvsagt helt afhængig af russisk støtte, hvilket tydeligt kom til udtryk, da Armenien ønskede at indgå en associeringsaftale med EU op til EU's Partnerskabs-topmøde i Vilnius i november 2013. Den armenske præsident blev indkaldt til en 'kammeratlig' samtale hos præsident Putin, hvorefter han besluttede, at Armenien meget hellere ville være med i den Eurasiske Økonomiske Union. Hvis Rusland trak sin politiske støtte og sine styrker ud af Armenien, ville det hurtigt føre til en genopblussen af den væbnede konflikt, og for Armenien ville det være en veritabel eksistenskamp.

EU kan ikke tilbyde Armenien nogen form for sikkerhedsgarantier og har et ambivalent forhold til de to parter, bl.a. fordi EU har betydelig energipolitisk interesse i gode forbindelser til Aserbajdsjan.

\section{Sydossetien og Abkhasien}

Rusland har siden krigene i begyndelsen af 1990'erne i Georgien opretholdt autonomien i Sydossetien og Abkhasien ved tilstedeværelse af russiske fredsbevarende enheder på et mandat fra SNG. Efter krigen med Georgien i august i 2008 har Rusland som tidligere nævnet anerkendt Sydossetien og Abkhasien som selvstændige nationer.

Den russiske tilstedeværelse i området før 2008 bl.a. var et middel til at øve indflydelse på Georgien og sikre russiske geopolitiske interesser. Udstationeringen af yderligere russiske styrker efter 2008 har haft til formål at fastlåse situationen for dermed at forhindre et muligt georgisk medlemskab af NATO, hvilket er et overordnet sikkerhedspolitisk mål for Rusland $i$ hele det post-sovjetiske rum.

Rusland har p.t. ca. 7.000 soldater i de to områder og udbygger baserne Ochamchire og Gudauta i Abkhasien og Kanchaveti i Sydossetien. Status quo efter 2008 ser ud til at ville blive opretholdt langt ud i fremtiden.

Men lad os antage, at den russiske støtte til de to udbryderrepublikker faldt bort. Det ville næppe ændre meget bortset fra, at det ville give Georgien mulighed for at løse konflikterne med militære midler. Intet som helst tyder på, at sydosseterne og abkhaserne ville affinde sig med at blive en del af Georgien og underlagt georgiske myndigheder.

Dertil kommer, at den demografiske situation har ændret sig. Ifølge FN’s Højkommissær for Flygtninge er ca. 230.000 personer flygtet eller fordrevet fra Abkhasien og Sydossetien.

\section{Transnistrien}

Den samme problematik gør sig gældende i Transnistrien, hvor den russiske eller snarere slaviske befolkning (der bor mange ukrainere i området) ikke ønsker at blive styret fra Chisinau (hovedstaden i Moldova, red.).

Moldova er etnisk, sprogligt og kulturelt beslægtet med Rumænien, der gerne ser Moldova indlemmet i landet. Moldova er kandidat til et egentligt EU-medlemskab, men de ret så kaotiske politiske forhold i landet bevirker, at medlemskabet ikke er umiddelbart forestående. Dertil kommer, at der bestemt ikke er enighed blandt moldoverne om et medlemskabs betimelighed. Tilpasningen til EU-lovgivning vil være svært ubekvem for dele af den politisk-økonomiske elite.

Det forekommer utænkeligt, at Transnistriens elite vil kunne tilslutte sig EU's acquis communautaire. Eliten i Tiraspol har gennem årene oparbejdet en selvstændig identitet med en gråzone- økonomi (for nu at udtrykke det pænt), som ikke ville være forenelig med EU's acquis. Dertil kommer, at man i perioder har været begunstiget af russisk økonomisk bistand, 
der imidlertid har været i kraftig tilbagegang i forbindelse med den russiske økonomiske krise. Transnistrien har desuden oparbejdet en gæld til Gazprom på ca. 1,8 mia. dollar, hvilket må siges at have skabt et afhængighedsforhold af et vist omfang.

Rusland er stadig militært til stede i Transnistrien med ca. 1.500 soldater, der bl.a. bevogter store ammunitionsdepoter. Opretholdelsen af status quo bidrager til at fremme russiske geopolitiske interesser, først og fremmest at forhindre Moldovas tilknytning til EU.

\section{EU's rolle}

En anden aktør i disse konflikter er EU, dog i mere begrænset omfang.

EU's Partnerskabsprogram omfatter Aserbajdsjan, Armenien, Georgien, Moldova, Ukraine samt Belarus, der dog har 'karantæne' på grund af menneskerettighedssituationen i landet.

Aserbajdsjan er ikke specielt interesseret i en nærmere tilknytning til EU, når det kommer til stykket. Det forekommer noget utopisk, at Baku skulle begynde at implementere EU's acquis communautaire eller Københavner-kriterierne for mindretalsretttigheder.

Armenien, Georgien, Moldova og Ukraine har forhandlet associeringsaftaler og Deep and Comprehensive Free Trade Agreements (DCFTA) med EU. Som nævnt har Armenien trukket sig ud, mens det i nogen grad står hen i det uvisse med Georgien og Moldova. Ukraine er en særlig problematik, der ikke skal behandles her.

I EU's sikkerhedsstrategi fra 2003 bliver det slået fast, at EU har klare interesser i forhold til de østlige naboer: Man ønsker en ring af velstyrede og stabile naboer i det østlige naboskab, og man anser de frosne konflikter som en trussel mod regional stabilitet. Men den fælles udenrigs- og sikkerhedspolitik er ikke et reelt alternativ til medlemsstaternes, især ikke til de store landes politik.

Det var Frankrig, der på vegne af EU mæglede i den russisk-georgiske krig i 2008, og det var Tyskland, der i 2010 med Meseberg-processen forsøgte at inddrage Rusland i et tættere sikkerhedssamarbejde for bl.a. at få løst op for konflikten i Moldova, hvilket ikke lykkedes.

EU's problem består først og fremmest $i$, at man kun har 'soft power' som instrument til at opnå de politiske mål. Man baserer sig på værdier og i mindre grad på interesser og er derfor afhængig af, at disse værdier og mål generelt set deles af de pågældende aktører, hvilket langtfra altid er tilfældet. Det afhænger af, om disse aktører opfatter EU's integrationsmodel som attraktiv.I forhold til konflikten i Nagorno-Karabakh kan EU næppe spille nogen afgørende rolle, men kan støtte forhandling og tillidsskabende foranstaltninger. I Georgien kan EU udbygge de økonomiske forbindelser og støtte en strategi, der fremmer tillidsskabende tiltag, som i sidste ende formentlig kun kan forhindre en eskalering af konflikterne samt reducere de negative konsekvenser af løsrivelsen af Abkhasien og Sydossetien.

Moldova tegnede i perioden umiddelbart efter påbegyndelsen af Mesebergprocessen til at blive den konflikt, hvor der var størst chance for et gennembrud. Men den politiske uenighed i Moldova om landets fremtidige kurs i forening med det faste russiske greb om Transnistrien og ikke mindst i lyset af konflikten i Ukraine gør et gennembrud nærmest usandsynligt.

EU kunne spille en rolle i konfliktløsning af frosne konflikter i det post-sovjetiske rum, men det ville kræve et tæt og tillidsfuldt samarbejde med Rusland, og det forekommer at være længere væk end nogen 
sinde. NATO-udvidelser er ikke problemet længere. Der kommer forhåbentligt ikke flere forsøg på at trænge ind i de russiske 'forhaver og baghaver', som russerne ynder at kalde det.

Sporene fra Georgien og Ukraine kan ikke undgå andet end at skræmme. I virkelighedens verden kan og vil Vesten ikke garantere disse landes sikkerhed over for verdens næststørste atommagt, uanset de mange floromvundne topmødeudtalelser.

Forholdet mellem EU og Rusland har de sidste 4-5 år været præget stigende rivalisering over EU's østlige naboer: Hvilken model for integration skal disse lande (EU's Partnerskabslande) vælge? Skal det være EU's acquis og dermed på sigt en form for medlemskab eller skal det være den russiske model, Toldunionen og den Eurasiske Økonomiske Union? Det er ren geopolitik.

Hvis the Deep and Comprehensive Free Trade Agreement, som EU har forhandlet med Ukraine, Moldova og Georgien implementeres, vil det have indflydelse på væsentlige russiske interesser. For Rusland vil implementeringen af acquis for EU’s Energi Fællesskab og i særdeleshed den 3. energipakke betyde væsentlige $ø$ konomiske tab samt tab af politisk indflydelse. En løsning, der også tilgodeser russiske interesser, er ikke i sigte, men er en af forudsætningerne for, at Rusland kan inddrages i en mere konstruktiv dialog om disse konflikter.

EU har opretholdt en ikke-anerkendelsespolitik over for disse udbryderstater, hvilket har medført en isolation og en vognborgsmentalitet, som vil gøre konfliktløsningen vanskelig.

Man kunne overveje pragmatiske tillidsskabende foranstaltninger, der retter sig mod civilsamfundene i det omfang, de i øvrigt findes, samt økonomiske incitamenter. Men sandheden er nok nærmere, at disse udbryderstaters politiske og økonomiske eliter frygter, at EU's involvering på sigt vil bringe deres de facto selvstændighed til ophør, og derfor har de allieret sig med de mest nationalistiske og antivestlige kredse i Rusland samtidig med at handelsforbindelserne til Rusland til stadighed udvikles og deres lovgivning harmoniseres med den russiske.

\section{OSCE og NATO}

To eksterne aktører har været kun været omtalt perifert, OSCE og NATO, og det kan gøres kort. OSCE har på det mere praktiske niveau haft stor betydning, først og fremmest ved organisationens observatører, men har også været en medspiller i forhandlingsprocesserne og de tillidsskabende tiltag, og det bør i virkeligheden være genstand for en selvstændig artikel; men OSCE er en tungt arbejdende organisation, baseret på konsensus blandt de 57 medlemmer og har i øvrigt ingen 'muskler'. OSCE har desuden været beskyldt af bl.a. Georgien for at være meget venligt indstillet over for Rusland, en noget tvivlsom påstand.

NATO har musklerne, men er ikke gearet til denne type opgave. En indblanding i disse konflikter ville få samtlige russiske alarmklokker til at ringe. Det er russisk indflydelsessfære, hvor NATO ikke har noget at gøre - efter russisk opfattelse. NATO har bidraget, i samarbejde med EU og OSCE, til at bilægge konflikterne på Balkan. Operationerne i BosnienHercegovina og Kosovo lykkedes i den forstand, at krigshandlingerne blev bragt til ophør, men det endelige resultat er nedslående: To fejlslagne stater på overførselsindkomster fra det internationale samfund.

Der er to modstridende principper, der hele tiden støder sammen i denne type konflikter: Staternes territoriale integritet og folkenes selvbestemmelsesret. Det 
EU kunne spille en rolle i konfliktløsning af frosne konflikter i det post-sovjetiske rum, men det ville kræve et tæt og tillidsfuldt samarbejde med Rusland, og det forekommer at være længere væk end nogen sinde.

er næsten som at skulle løse cirklens kvadratur.

I den internationale politikteori nævnes regional integration, som en mulig løsningsmodel, men det er ikke lige det, der ligger i kortene i en overskuelig fremtid. Jo længere tid, der går, jo mere cementeret bliver de løsrevne områders autonomi, jo vanskeligere bliver en konfliktløsning.

Disse konflikter løser ikke sig selv, men kræver det internationale samfunds involvering. Der kan spores en vis ulyst mod at engagere sig. Udsigten til succes er ikke stor, og derfor vil indsatsen næppe stå mål med det forventelige resultat. Dertil kommer det uundgåelige sammenstød af geopolitiske interesser, der gør aktørerne forsigtige, og som gør det vanskeligt for organisationer som fx OSCE at udnytte sit potentiale.

Derfor trækkes vi stadig, 25 år efter den kolde krigs ophør, med disse konflikter, der på overfladen måske nok er frosne, men som i virkeligheden under overfladen er varme kartofler, som har potentiale til at udvikle sig til brandvarme kartofler

\section{Ny frossen konflikt?}

I indledningen blev det antydet, at en ny frossen konflikt er sandsynlig i det østlige Ukraine. De to såkaldte folkerepublikker Donetsk og Luhansk ligner potentielle kandidater. Meget tyder på, at kamphandlingerne standser ved den våbenstilstandslinje, der blev fastlagt ved Minsk II aftalen, om end der til stadighed er skudepisoder.

Hvis man ikke kan gennemføre hele aftalen, herunder afholde valg efter Kievs valglove i de to 'folkerepublikker', hvilket forekommer ret usandsynligt, er der to umiddelbare muligheder. Den første indebærer en fastfrysning af situationen, den anden indebærer en fortsættelse af kampene. Det kunne indebære et forsøg fra separatisterne, med hel eller delvis skjult russisk støtte, på at erobre Mariupol og Novorossija, hvorved der skabes direkte forbindelse til Krim.

Den sidste option kan være fristende for Rusland, og de ultra-nationalistiske kræfter i Rusland lægger et stort pres på Kreml; men den indebærer betydelige risici for uønskede reaktioner fra det internationale samfund, fortrinsvis Vesten. For Rusland er det muligvis tilstrækkeligt at sikre en 'kontrolleret ustabilitet', hvorved man begrænser de ukrainske handlemuligheder. Dermed er der føjet en ny 'frossen konflikt' til listen.

Så langt tilbage som i 1959 beskrev professor Kenneth Waltz i Man, the State and War det internationale system som værende præget af relativt anarki. Man må konstatere, at denne tilstand er stadig gældende. 